A
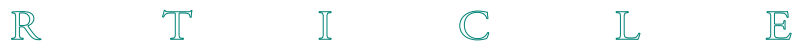

\title{
Dorota Gregorowicz
}

Università degli Studi del Piemonte Orientale 'Amedeo Avogadro'

\section{FINAL REPORTS OF PAPAL DIPLOMATS AS A CULTURAL MESSAGE: THE CASE OF THE POLISH-LITHUANIAN COMMONWEALTH}

\begin{abstract}
This paper focuses on the cultural and political importance of papal nuncios' final reports (relazioni finali) as one of the basic sources of knowledge about the PolishLithuanian Commonwealth in the Roman Curia. The final report was a document, in essence a summary, which a diplomat was required to complete at the end of his mission (or immediately after). During the creation of the office of permanent nuncio to the major European courts, the preparation and delivery of the final report often took place orally. Gradually, the relazione evolved into a written version. Throughout the sixteenth century, when knowledge about Poland-Lithuania in Rome was rather poor, the relazioni finali consisted of colourful descriptions of the geography, the history, and the social and political relations of the Polish-Lithuanian Commonwealth. During the seventeenth century, this document became more political in character. It related directly to the activities of the papal diplomats, rituals and ceremonials, and any particular problems regarding the missions, rather than extensive descriptions of relatively banal curiosities. Throughout the seventeenth century in particular, when a permanent papal diplomatic presence had just been established in Poland-Lithuania, the final reports were an important contribution to future missions. Newly-appointed nuncios therefore willingly used the extremely important information contained therein. The practice of writing relazioni finali made it easier for the Holy See to consolidate its diplomatic influence and presence in Central and Eastern Europe in the early modern period. It also fostered papal interest in the social and political features of the enormous 'noble' republic.
\end{abstract}

Keywords: Diplomacy, papacy, Poland, Lithuania, final reports, nunciature 
The crisis of political history, evident in post-war historiographical discourse, automatically caused a decline of interest in the history of diplomacy. ${ }^{1}$ Today, historians are more willing to analyse not only the political, but also the cultural aspects of diplomatic negotiations. The history of diplomacy has accordingly become a history of trans-border contacts, and examines varying geographic and cultural factors. Historians therefore analyse manifestations of political culture, as well as economic, social and dynastic mechanisms, which helped to determine specific political and diplomatic actions. Early modern international communication not only had political objectives, but also facilitated coexistence and mutual understanding between peoples of different countries, as well as an appreciation of different cultures.

The historical sources that historians most commonly employ to conduct research on cultural aspects of diplomacy are usually public writings, correspondence and orations. ${ }^{2}$ Here I wish to focus on a specific genre of document: namely, early modern papal final reports (relazioni finali). The region under investigation here is Poland-Lithuania. These documents, prepared by papal nuncios serving in the Polish-Lithuanian Commonwealth, are a significant source of information and opinions that contributed to papal, Italian and Western European perceptions of Central and Eastern Europe in the early modern period. ${ }^{3}$

The establishment of permanent apostolic nunciatures at the major Catholic courts permitted the Holy See to extend further its interest in (and control over) states and regions on the periphery of Catholic Europe. The Polish-Lithuanian Commonwealth was one such state in the late

${ }^{1}$ Wojciech Tygielski, Z Rzymu do Rzeczypospolitej: Studia z Dziejów Nuncjatury Apostolskiej w Polsce, XVI-XVII w. (Warsaw: Wydawnictwa Fundacji 'Historia pro Futuro', 1992), p. 6; Stefano Andretta, L'Arte della Prudenza: Teorie e Prassi della Diplomazia nell'Italia del XVI e XVII Secolo (Rome: Biblink, 2006), p. 7.

2 Daniela Frigo, 'Politica Estera e Diplomazia: Figure, Problemi e Apparati', in Storia degli Antichi Stati Italiani, ed. by Gaetano Greco and Mario Rosa (Rome: Laterza, 1996), pp. 117-61; Lucien Bély, 'Histoire de la Diplomatie et des Relations Internationales des Temps Modernes: Un État de la Recherche en France', in Sulla Diplomazia in Età Moderna: Politica, Economia, Religione, ed. by Renzo Sabbatini and Paola Volpini (Milan: FrancoAngeli, 2011), pp. 19-34 (p. 30).

${ }^{3}$ Henryk Damian Wojtyska, Papiestwo - Polska 1548-1563 (Lublin: Towarzystwo Naukowe Katolickiego Uniwersytetu Lubelskiego, 1977), p. 11. 
sixteenth century. Among the main papal objectives in Poland-Lithuania, one can discern the construction of a new Catholic league, the potential conversion to Catholicism of Orthodox Russia and Protestant Sweden, and, finally, the continued spread of the Counter-Reformation. For the papacy, it was also important to maintain a certain political balance in Central and Eastern Europe. Antonio Maria Graziani, papal secretary for Polish affairs, wrote a memorandum to Cardinal Girolamo Rusticucci in January 1587, in which he emphasised the strategic importance of Poland-Lithuania to the Holy See:

The Kingdom of Poland, due to its greatness and for its location, is a true bulwark of Christendom. It is opposed many barbarous nations, and it cannot fall, without having collapsed into ruins and opening a large gate to the enemies of our faith. ${ }^{4}$

The increase of papal interest in the affairs of Poland-Lithuania led to an automatic rise in demand for a wide variety of information about it. ${ }^{5}$ This collection of data was in fact the nuncio's most important task during his mission. ${ }^{6}$ The relazione finale can be described as the culmination of a diplomat's activity, in which he presented a summary of all the information he had gleaned concerning his host nation. ${ }^{7}$ In this analysis, I wish to focus on the cultural importance of the papal nuncios' final reports, as one of the Roman Curia's basic sources of knowledge about the Polish-Lithuanian Commonwealth.

${ }^{4}$ Letter from Antonio Maria Graziani to Girolamo Rusticucci, [January 1587], in Jan Władysław Woś, Fonti per la Storia della Nunziatura Polacca di Annibale di Capua (1586-1591) (Trento: Università di Trento, Dipartimento di Scienze Filologiche e Storiche, 1992), p. 64: 'Il Regno di Polonia, ch'essendo et per la grandezza et per le forze et per il sito, un vero antemurale de la christianità, opposto a molte barbare nazioni, non può cadere, che non si tiri dietro gran ruina et non apra una gran porta a gli nemici della nostra fede.' All the translations present in the article are those of the author.

5 Frigo, pp. 117-61 (p. 136).

${ }^{6}$ Matthew Smith Anderson, The Rise of Modern Diplomacy 1450-1919 (London: Longman, 1993), p. 13.

See: Eric Dursteler, 'Describing or Distorting the 'Turk'? The Relazioni of the Venetian Ambassadors in Constantinople as Historical Sources', Acta Histriae, 19 (2011), 232-48 (p. 237). 


\section{THE MAIN CHARACTERISTICS OF THE PAPAL RELAZIONI FINALI IN THE SIXTEENTH AND SEVENTEENTH CENTURY}

The papal relazioni finali were inspired by the famous Venetian reports, the importance of which was still evident in the nineteenth century, particularly to the eminent historians Johannes von Müller and Leopold von Ranke. ${ }^{8}$ Since the Middle Ages, the Venetian relazioni finali had been diligently stored in order to create a database of documents which would serve to prepare future ambassadors of La Serenissima for their missions. ${ }^{9}$ The Roman curia adapted this practice around the beginning of the sixteenth century.

During the evolutionary stage of the office of a permanent nunciature, the final reports were usually delivered orally in Rome, after the mission's conclusion. During the first half of the sixteenth century, it was the most common form of submission. This practice is occasionally mentioned in Acta concistoralia and in the guidelines to ceremonial at the papal court. ${ }^{10}$ Hints at such a delivery of a relazione finale from Poland-Lithuania were left behind by Thomas Crnic (Crnić, Negro) (1522-1523) and Girolamo Martinengo (1548). Marco Antonio Maffei (1553) probably also submitted a verbal report. ${ }^{11}$ Only gradually, then, did the final reports evolve into written texts, which allowed for the introduction of a more elegant, literary and rhetorical style. ${ }^{12}$ In any case, they still tended to be presented orally in some circumstances, especially following cardinal-legates' missions. Cardinal Ippolito Aldobrandini (the future Pope Clement VIII), who served as legate to the Commonwealth between 1588 and 1589, submitted his report to the

${ }^{8}$ Dursteler, 232-48 (p. 233).

9 Wojtyska, Papiestwo - Polska, p. 226; Alain Tallon, L'Europa del Cinquecento: Stati e Relazioni Internazionali (Rome: Carocci, 2013), p. 199.

${ }_{10}$ Marc Dykmans, Le Céremonial Papal de la Fin du Moyen Age à la Renaissance. II: De Rome en Avignon ou le Céremonial de Jacques Stefaneschi (Brussels: Institut Historique Belge de Rome, 1981), pp. 499-500: 'In proximo vero consistoio secuturo, dicti nuntii vel legati referunt sue relationem faciunt de gestis per eos in legationibus suis; et hoc per modum collationis, rcipiendo thema aliquale. Et istud servatur etiam si sint duo legati vel nuntii sive plures, pro quibus <unus> facit suam relationem per modum collationis.'

11 Wojtyska, Papiestwo - Polska, p. 226.

12 Dursteler, 232-48 (p. 237). 
consistory convened on 5 June 1589. Enrico Caetani, who was the papal legate in the years 1596-1597, reported on his stay in Poland-Lithuania during the consistory which assembled on 16 June 1597. The final report of nuncio Pietro Vidoni was also delivered verbally, directly to his successor Antonio Pignatelli, on 27 August 1660. ${ }^{13}$

Throughout the sixteenth century, when knowledge of PolandLithuania in Rome was still poor, the relazioni finali generally consisted of colourful descriptions of geography, history, and social and political relations in the Commonwealth. As Donald Queller stated:

Behind the foreground of princes and courts, there was greater consciousness of lands and peoples. Curiosities came to abound, sometimes to the point of abuse. Relazioni acquired a more erudite and bookish character, less dependent upon the immediate experience of the ambassador. There was more ordered and patient analysis. Geographical information was abundant, in part for its own sake, in part in relation to its economic, military and ethnic importance. There was a stronger interest in commercial resources and in social class. Relazioni became increasingly generalised essays on the country from which the ambassador had returned. ${ }^{14}$

Such was the case of the reports analysed below, written by Luigi Lippomano, Giulio Ruggieri, Vincenzo Dal Portico and Alberto Bolognetti. It was partly true also in Galeazzo Marescotti's seventeenth-century relazione. Nevertheless, during the seventeenth century, the final reports of papal diplomats came to focus primarily on political affairs. The relazioni of Germanico Malaspina, Honorato Visconti and Galeazzo Marescotti revealed perceptive political analysis. Their reports related directly to the specific activities and tasks of papal diplomats, to questions of ceremonial and precedence, and to particular problems regarding the missions, rather than dwelling on trifles and curiosities. Thus, they came to resemble a manual of instruction for their successors in Cracow. ${ }^{15}$

${ }^{13}$ Henryk Damian Wojtyska, Acta Nuntiaturae Polonae: De Fontibus Eorumque Investigatione et Editionibus Instructio ad Editionem Nuntiorum Series Chronologica (Rome: Institutum Historicum Polonicum Romae, 1990-2016), I (1990), p. 261 (hereafter cited as: ANP I).

14 Donald Queller, 'The Development of Ambassadorial Relazioni', in Renaissance Venice, ed. by John Rigby Hale (London: Faber and Faber, 1973), pp. 174-96 (p. 183).

15 This kind of evolution took place thanks to the sufficient accumulation of general knowledge about Poland-Lithuania in the Roman Curia. See: Wojtyska, Papiestwo - 
The general model of papal relazione finale, structured on the Venetian one, was a helpful prototype in which the collected observations were organised systematically. Its encyclopaedic nature guaranteed the transparency and the completeness of the information included. The Venetian format also specified the criteria for the collection of information. This model was generally as follows: the nuncio should discuss the location of the country described, with its boundaries, administrative divisions, cities, and principal geographic features. He should subsequently describe the climate, natural resources, and landscape. A description of society generally followed, with its economy, customs, traditions, ceremonies, and laws. The author should then provide a pen-portrait of the reigning monarch, complete with their family, court, authority and power, their income and expenditure. Following this, he was required to describe and analyse military issues, as well as the local Catholic Church's organisation. Finally, diplomats included a description of the bordering states and their rulers, as well as a selection of the most important political realities concerning the Polish-Lithuanian Commonwealth. ${ }^{16}$

Nevertheless, the nuncios did not need to adhere strictly to this model. The nature of relazioni finali left them a lot of freedom as regards both form and subject matter. Much depended on the personal interests and opinions of the authors, as well as on the course of events during an individual's tenure as nuncio. ${ }^{17}$ There was also scope for diplomats to express their own opinions or judgements. This is clear through the use of phrases such as 'in my opinion', which occasionally appeared in documents. ${ }^{18}$ The report's narrative was usually presented in the first person, but there are also cases of use of the third person. For example, the papal nuncio Germanico Malaspina generally described himself as

Polska, pp. 226-28; Wojciech Tygielski, 'Źródła Informacji Papieskich Dyplomatów', in Nuncjatura Apostolska w Rzeczypospolitej, ed. by Teresa Chynczewska-Hennel and Katarzyna Wiszowata-Walczak (Białystok: IHiNP UWB, 2012), pp. 27-44.

16 Queller, pp. 174-96 (p. 181); Frigo, pp. 117-61 (pp. 143-45); Tallon, p. 199.

17 Queller, pp. 174-96 (p. 181).

18 Giulio Ruggieri, Iulii Ruggieri Relatio Generalis, 1568, in Acta Nuntiaturae Polonae: Iulius Ruggieri (1565-1568), ed. by Stanisław Bogaczewicz and Tadeusz Glemma (Rome: Institutum Historicum Polonicum Romae, 1990-2016), VI (1991), p. 171 (hereafter cited as: Ruggieri). 
Monsignor Malaspina. ${ }^{19}$ Moreover, a diplomat did not necessarily prepare his relazione finale after returning to Rome. Many of the final reports were written when the nuncio was still in Poland-Lithuania, during the course of his duty. ${ }^{20}$ This happened, for example, in the case of Mario Filonardi, who served in Poland from 1636 to 1643 . He composed his relazione in 1640, three years before his mission concluded. ${ }^{21}$

Despite the very interesting character of relazioni finali as historical sources, historians cannot place complete trust in their content, since the point of view of the nuncio who composed it was always closely linked to his origins, his education, and to the confessional nature of his mission. A limited range of direct social contacts and long-standing exposure to the cosmopolitan and sophisticated royal court could contribute to a lack of objectivity, both in diplomatic correspondence and in final reports. Papal diplomats, however, always tried to have as wide a range of contacts as possible, which could assist them in gaining thorough insights. They were loath to be completely separated from the society of the country to which they had been assigned.

In any case, errors quite often appeared in the relazioni finali. The nuncios tended to write about almost everything they observed, even if they lacked the expertise to comment with authority. Ruggieri acknowledged this problem, in writing about the defence of PolandLithuania: 'Military questions are far removed from my profession, but they constitute a basis of that Kingdom's policy. ${ }^{22}$ Mistakes happened routinely, therefore. Vincenzo Dal Portico reported, for example, that the city of Warsaw was located in Greater Poland, while in fact it was the capital of the Mazovia region. Moreover, he wrongly suspected that the number of nobles in the Commonwealth exceeded the number of

19 Germanico Malaspina, Relacya o Polsce przez Nuncyusza Malaspina roku 1598, mająca zarazem stużyć za instrukcya dla jego następcy, 1598, in Relacye Nuncyuszów Apostolskich i Innych Osób o Polsce od Roku 1548 do 1690, ed. by Erazm Rykaczewski, 2 vols (Berlin: Biblioteka Polska w Paryżu, 1864), II, p. 86 (hereafter cited as: Malaspina).

${ }^{20}$ Wojtyska, Papiestwo - Polska, p. 226.

21 ANP I, p. 257.

22 Ruggieri, p. 178: 'La militia, molto lontana dalla professione mia, ma principale fondamento della politia di quel Regno.' 
townspeople and peasants put together. ${ }^{23}$ Galeazzo Marescotti stated that the ancient Polish gods were those of the Romans: Jupiter, Pluto, Diana, Mars, Mercury and Venus. ${ }^{24}$ Furthermore, there were a number of transcriptional errors in the relazioni. These were usually derived from general difficulties related to the spelling and pronunciation of Slavic names.

\section{THE IMPORTANCE OF FINAL REPORTS}

Vincent Ilardi considered diplomacy to be 'an expression of all activities regarding a certain state', facilitating understanding and accepting the conventions of a foreign society. ${ }^{25}$ During the early modern period, cultural diplomacy as we understand it was not yet a true diplomatic strategy, even if, subconsciously, it was widely practiced. In fact, as noted above, the activity of early modern papal diplomats should be understood not only in terms of political machinations, but also in a cognitive context, for the purposes of observing and understanding previously unknown political, social, economic or cultural environments. ${ }^{26}$

${ }^{23}$ Archivio Segreto Vaticano, Segreteria di Stato, Polonia 5b, Relatione del Regno di Polonia 1572, a copy presented also in: bid.; Biblioteka Naukowa PAU/PAN, Teka Rzymska 127, p. 19 (hereafter cited as: Dal Portico). NB: Thanks to the remark made by Klaudia Ewelina Gumieniak, it has been realised that the same relazione, translated into Polish, was already published twice (Fulvio Ruggieri, Opis Polski przez Mons. Fulwiusza Ruggieri w roku 1565, in Relacye Nuncyuszów, I, pp. 113-165 and, in fragments, as F. Ruggieri, Opis Polski w roku 1565 in Cudzoziemcy w Polsce. Relacje i opinie, ed. by Jan Gintel, 2 vols [Kraków: Wydawnictwo Literackie, 1971], I, pp. 127-138). Nevertheless, as presumed by Henryk Damian Wojtyska (Acta Nuntiaturae Polonae: De fontibus eorumque investigatione et editionibus. Instructio ad editionem. Nuntiorum series chronologica, ed. by Henryk Damian Wojtyska [Rome: Institutum Historicum Polonicum Romae, 1990-2016], I [1990], p. 217), and according to the dates present in the manuscripts cited above, the document could not have been written during Fulvio Ruggieri's stay in Poland (1563-1565). Moreover, its character and construction is clearly attributable to the apostolic nuncios' documentary production, and not a simple legate's secretary's as Ruggieri.

${ }^{24}$ Galeazzo Marescotti, Opisanie dworu, rzeczypospolitej i królestwa polskiego przez Galeazzo Marescotti, arcybiskupa Koryntu, nuncyusza Stolicy Apostolskiej w latach 1670 i 1671, 1671, in Relacye Nuncyuszów, II, p. 365 (hereafter cited as: Marescotti I).

${ }^{25}$ Frigo, pp. 117-61 (p. 118).

26 Ibid., pp. 117-61 (pp. 142-44); Andretta, p. 14. 
Early modern Rome has traditionally been described as a 'theatre' or a 'workshop of world practices', not without good reason. It constituted the most important European centre for the exchange of information and gossip. ${ }^{27}$ Moreover, the fact that the papal government issued the reports generally served to increase the credibility of the information included therein. The relazioni finali constituted a part of the literary current of notitia rerumpublicarum. Their content was not secret, but they remained handwritten and were not printed. They were widely read, transcribed, and ultimately stored in the archives of many Italian families, especially those of diplomats - authors of the reports. ${ }^{28}$ Relazioni finali an be found in the archives of the Strozzi, Chigi, Barberini, Borghese, Corsini and Ottoboni casate. We can find them also in various collections at the Biblioteca Ambrosiana in Milan, the Biblioteca Vallicelliana in Rome, the Biblioteka Książąt Czartoryskich in Cracow, the Biblioteka PAN in Kórnik and in the Biblioteca Apostolica Vaticana’s divisions Urbinati and Vaticani Latini. Nonetheless, most of the final reports are preserved in the Vatican Archives in the section Segreteria di Stato, Polonia. The relazioni finali were also willingly collected by humanists and scholars. Their circulation allowed for the dissemination of information on Poland-Lithuania across Italy and Western Europe as a whole. The sheer number of copies is proof of their high popularity and wide distribution. The final reports facilitated cognitive reflection on distant countries and lands, on their culture, on their social and economic structures, and on the political ideas which circulated among intellectuals and government members. ${ }^{29}$

In Queller's words, 'the Relazione provided a broad and comprehensive synthesis, periodically brought up to date by successive ambassadors, of the political military, economic, and social conditions of the country visited. ${ }^{30}$ For the Roman Curia, the final reports contributed significantly to future missions. This was especially the case during the sixteenth

27 Anderson, p. 13; Andretta, p. 47; Maria Antonietta Visceglia, Roma Papale e Spagna: Diplomatici, Nobili e Religiosi tra le Due Corti (Rome: Viella, 2010), p. 43.

28 Teresa Chynczewska-Hennel, Rzeczpospolita XVII Wieku w Oczach Cudzoziemców (Wrocław: Zakład Narodowy im. Ossolińskich, 1993), pp. 21-22.

${ }^{29}$ Frigo, pp. 117-61 (pp. 143-45).

30 Queller, pp. 174-96 (p. 175). 
century, when the apostolic nunciature had just been established in Poland-Lithuania. The newly designated nuncios enthusiastically used the information provided to prepare themselves for their new roles. Furthermore, large extracts of relazioni finali were transcribed and added to the instructions for the new diplomatic appointees. This reality clearly emerges from a comparison of the contents of these two genres of documents. ${ }^{31}$ Moreover, the final reports of Alberto Bolognetti, Girolamo Bovio, Germanico Malaspina, Antonio Santacroce and Antonio Pignatelli contained a postscript: ad informationem successoris, which provides us with the main purpose of the document. ${ }^{32}$ In cases where the report also included instructions for a successor, the author made suggestions for concrete actions which his successor should undertake. It was also common for authors of the final reports to express opinions and suggestions as to the appropriate conduct both of the nuncio (and more generally, of the Holy See) towards Poland-Lithuania. It frequently transpired that the correspondence and the relazioni finali of a nuncio's predecessors constituted the preparatory literature for the new mission. Such was the case of the Archbishop of Naples, Annibale Di Capua, who arrived in Poland-Lithuania in 1587. He derived his knowledge of the Commonwealth from the extensive report of Alberto Bolognetti. ${ }^{33}$

Not all the nuncios compiled a final report, and of those who did, some of their relazione have not survived. According to the study made by Henryk Damian Wojtyska, over the course of the sixteenth and seventeenth centuries, the relazioni finali of the following diplomats are currently missing: Zaccaria Ferreri (1519-1521), Giovanni Antonio Puelleoni (1524-1526), Giovanni Francesco Cito (1525-1527), Pamphilio Strassoldo (1536), Girolamo Rorario (1539-1540), Otto Truchsess a Waldburg (1542), Camillo Mentovato (1558-1559), Giovanni Francesco Commendone (1563-1565), Giovanni Andrea Cagliari (1578-1581), Annibale Di Capua (1586-1591), Jerzy Radziwiłł (1592), Francesco Simonetta (1606-1612), Lelio Ruini (1612-1614), Francesco Diotallevi (1614-1621), Giovanni Battista Lancelotti (1622-1627),

31 Wojtyska, Papiestwo - Polska, p. 227

${ }^{32}$ ANP I, pp. 255, 227, 235, 252, 264.

33 Tygielski, $Z$ Rzymu do Rzeczypospolitej, p. 126. 
Giovanni de Torres (1645-1652), Angelo Maria Ranuzzi (1671-1673), Francesco Buonvisi (1673-1675), Optio Pallavicini (1680-1688) and Andrea Santacroce (1690-1696). We know that the report of Giovanni Antonio Davia (1696-1700) was written, but no copy has survived. ${ }^{34}$

On the other hand, we know of at least nineteen final reports of papal diplomats who were appointed to the nunciature of Poland-Lithuania during the sixteenth and seventeenth centuries. Their authors were: Niccolò Fabri (1525-1526), Luigi Lippomano (1555-1557), Berardo Bongiovanni (1560-1563), Giulio Ruggieri (1565-1568) Vincenzo Dal Portico (1568-1573), Vincenzo Lauro (1573-1578), Alberto Bolognetti (1581-1585), Girolamo Bovio (1584-1587), Germanico Malaspina (1592-1598), Claudio Rangoni (1598-1607), ${ }^{35}$ Cosimo de Torres (1621-1622), ${ }^{36}$ Antonio Santacroce (1627-1630), ${ }^{37}$ Honorato Visconti (1630-1636), Mario Filonardi (1635-1643), Antonio Pignatelli (1660-1668), Galeazzo Marescotti (1668-1670), Francesco Nerli (1670-1671), Franesco Martelli (1675-1681) and Jacopo Cantelmo (1687-1689). In the following paragraphs, I will discuss the relazioni finali of Lippomano, Buongiovanni, Ruggieri, Dal Portico, Bolognetti, Malaspina, Visconti and Marescotti.

\section{THE VARIETY OF INFORMATION}

The variety of information present in the relazioni finali is significant. In this article, my intention is to highlight their cultural and cognitive aspects, with less emphasis on the nuncios' purely political analysis. Papal relazioni finali regarding Poland-Lithuania generally commenced with a general historical background, explaining the history of the Piast

${ }^{34}$ ANP I, pp. 197-286.

35 Stanisław Bodniak, 'Polska w Relacji Włoskiej z Roku 1604', Pamiętnik Biblioteki Kórnickiej, 2 (1930), 26-49. See: Henryk Litwin, Chwata Pótnocy: Rzeczpospolita $w$ Europejskiej Polityce Stolicy Apostolskiej w Pierwszej Potowie XVII Wieku (1599-1648) (Lublin: KUL, 2013), pp. 110-11.

36 Litwin, p. 167

37 Honorato Visconti Breve relazione dello stato del regno di Polonia a monsignor Ill. mo Nuntio di Sua Santita nel 1630, June 1630 in Acta Nuntiaturae Polona: Honoratius Visconti (1630-1636), ed. by Wojciech Biliński (Rome: Institutum Historicum Polonicum Romae, 1990-2016), XXIV/1 (1992), pp. 16-32. See: Litwin, pp. 238-41. 
and Jagiellonian dynasties, as well as the origins of Christianity on Polish soil..$^{38}$ It is noticeable that most of the descriptions were carried out separately for the Kingdom of Poland and for the Grand Duchy of Lithuania. Some final reports began by explaining the name of Poland. Vincenzo Dal Portico and Galeazzo Marescotti correctly traced this term to the Slavic word pole. More puzzling was Dal Portico's explanation of the derivation of the word Polacco from Leco, the legendary Polish ruler. ${ }^{39}$ Nuncios also included descriptions of the tribal origins of Polish-Lithuanian society. ${ }^{40}$ Early modern diplomats were convinced that knowledge of the past was the best way to understand contemporary political and social processes. ${ }^{41}$

Unsurprisingly, papal diplomats paid a lot of attention to court intrigue and gossip. They provided written portraits of the important personages of the Commonwealth, and evaluated their potential usefulness to the Roman Curia. ${ }^{42}$ Further important elements of relazioni finali were the identification of existing political parties and alliances, and

38 Luigi Lippomano, Regni Polonae gentiumque finitimarum descriptio, January 1557 in Acta Nuntiaturae Polonae: Aloisius Lippomano (1555-1557), ed. by Henryk Damian Wojtyska (Rome: Institutum Historicum Polonicum Romae, 1990-2016), III (1992), p. 299 (hereafter cited as: Lippomano); Dal Portico, pp. 2-3.

39 Dal Portico, p. 2; Marescotti I, p. 361.

40 Ruggieri, p. 150.

41 Queller, pp. 174-96 (p. 176).

${ }^{42}$ Honorato Visconti, Zdanie sprawy z nuncyatury $w$ Polsce przez Honorata Visconti, arcybiskupa Larissy, nuncyusza papieża Urbana VIII, podane na ręce kardynata Barberino, 15 July 1636 in Relacye Nuncyuszów, II, pp. 220-60 (hereafter cited as: Visconti); Galeazzo Marescotti, Opis Polski ztożony papieżowi Klemensowi X przez nuncyusza kardynata Marescotti, [n.d.] in Relacye nuncyuszów, II, pp. 393-400 (hereafter cited as: Marescotti II). See: Paolo Brezzi, La Diplomazia Pontificia (Milan: Istituto per gli Studi di Politica Internazionale, 1942), p. 19; Wojciech Tygielski, 'Opinie Nuncjuszy Apostolskich na Temat Polski XVI-XVII w.', Przeglad Historyczny, 85 (1994), 351-62 (p. 361); Wojciech Tygielski, 'Geograficamente Distanti ma Spiritualmente Vicini: La Realtà Politica e Sociale Polacca del XVI e del XVII Secolo agli Occhi dei Nunzi Apostolici', in Kurie und Politik: Stand und Perspektiven der Nuntiaturberichtsforschung, ed. by Alexander Koller (Tübingen: Niemeyer, 1998), pp. 226-35 (p. 233); Chynczewska-Hennel, Rzeczpospolita XVII Wieku, p. 130; Luca Riccardi, 'An Outline of Vatican Diplomacy in the Early Modern Age', in Politics and Diplomacy in Early Modern Italy: The Structure of Diplomatic Practice, 1450-1800, ed. by Daniela Frigo (Cambridge: Cambridge University Press, 2000), pp. 95-108 (p. 108). 
accompanying analyses of personal conflicts and rivalries. ${ }^{43}$ The nuncios also generally included a detailed description of the currently reigning King and his entourage. ${ }^{44}$ The nuncios devoted similar attention to the members of the royal family. ${ }^{45}$

Other important aspects of the reports were the descriptions of the geography of the extensive territories of Poland-Lithuania. Firstly, the nuncios typically executed an accurate description of the boundaries of Rzeczpospolita. These were outlined as follows: from the north - the Baltic Sea, in the east - the rivers Dnieper and Dniester, from the south the mountain range of the Carpathians and in the west - the rivers Oder and Vistula. ${ }^{46}$ Following this broad delineation, papal diplomats would list the provinces included in the Polish-Lithuanian Commonwealth: the Kingdom of Poland with Greater and Lesser Poland, Mazovia, Pomerania, Prussia, Ruthenia and Podolia, the Grand Duchy of Lithuania, Samogitia and Livonia. ${ }^{47}$ Here, the authors generally also presented a short description of the bordering countries and the neighbouring rulers. ${ }^{48}$

The nuncios, accustomed to the mountainous landscapes of Italy, tended to pay particular attention to the vast plains which extended across almost the entire territory of the Commonwealth. 'All provinces are flat, except for Prussia and Lesser Poland, full of hills and valleys, with mountains where Poland borders with Hungary' wrote Giulio Ruggieri. ${ }^{49}$ Dal Portico employed similar descriptive terms: 'The countryside is almost all flat, especially in that part which faces the north and the west, and in the east, where the region of Podolia is. [...] The high

43 Malaspina, p. 91.

44 Lippomano, pp. 300-01; Berardo Buongiovanni, Opisanie królestwa polskiego przez Berarda Bongiovanni, biskupa Kamerińskiego, z roku, 1560 in Relacye nuncyuszów, I, pp. 98-100 (hereafter cited as: Bongiovanni); Dal Portico, pp. 38-43; Malaspina, pp. 96-97, Visconti, pp. 189-96, Marescotti II, pp. 389-92.

45 Visconti, pp. 211-17.

46 Ruggieri, p. 147; Dal Portico, pp. 4-5.

47 Lippomano, p. 299; Ruggieri, p. 147; Dal Portico, pp. 4-5; Marescotti I, pp. 362-65.

48 Dal Portico, pp. 4-5; Marescotti II, pp. 400-05.

49 Ruggieri, p. 147: 'Provincie tutte poste in piano, eccetto la Prussia et la Polonia Minore, repiene di molti colli et valli, et non senza monti ancora da quella parte, ove la Polonia confina con la Ungheria.' 
mountains are only towards Hungary. ${ }^{150}$ Lippomano also pointed out the lowland character of Rzeczpospolita, ${ }^{51}$ while Ruggieri added information concerning the abundance of rivers and lakes..$^{52}$

The nuncios also left some interesting testimonies concerning the climate of Poland-Lithuania, and they frequently complained about the difficulties that the weather caused to their missions. Cold winters were a regular source of complaint. ${ }^{53}$ Giulio Ruggieri affirmed:

The air is heavy and misty and as a result of the distance from the sun, it is very cold; this causes a lot of snow and ice, such as supports carriages easily, even when loaded. [...] The winds here are not as forceful as those of France or in Italy. ${ }^{54}$

Invariably the nuncios discussed the particular abundance of fauna. They listed moose, bison, wild horses, and beavers as species characteristic for Rzeczpospolita. In addition to those mentioned above, they recorded others widely known in Western Europe, such as hares, rabbits, deer, wild boar, and wolves. ${ }^{55}$ Vincenzo Dal Portico also described several of the hunting traditions of the nobility and of the royal court, including the special rituals of hunting prestigious animals like bison and bears. ${ }^{56}$

Another important aspect to which papal diplomats devoted frequent attention was the multiculturalism of Poland-Lithuania. Indeed, within this large territory, the pacific coexistence of various religions, confessions, laws and languages was quite simply necessary. Nuncio Ruggieri, who noted the mutual similarities which characterised the Slavic languages, left an interesting account of the linguistic diversity of the country:

50 Dal Portico, p. 6: 'Il paese è quasi tutto piano, e massime quella parte, che guarda verso settentrione e l'occidente e quella che è orientale dove è la Podolia. [...] I monti alti sono solamente dalla banda di Ungheria.'

51 Lippomano, p. 299.

52 Ruggieri, p. 148.

53 Marescotti I, p. 362.

54 Ruggieri, p. 149: 'L'aria poi è grossa et humida et per la distanza del sole molto fredda; onde si causa grandissima copia de nevi et ghiacci, tali che sostengono facilmente li carri, benché carichi. [...] I venti non vi regnano al pari di Francia o d'Italia.'

55 Dal Portico, pp. 14-17.

56 Ibid., pp. 15-16. 
Even though they live under the same prince, constituting a unified and almost indistinct political body, they do not speak the same language. You can hear in that Kingdom three different languages. One of them is divided into two different alphabets, but is pronounced in a very similar way. Even if the dialects vary, they maintain the substance of the same language. And these [dialects] are Polish and Russian. The first is written with Latin characters and the other with Greek ones [...] In addition, you can hear two other languages in these countries, completely different. These are Lithuanian and German. ${ }^{57}$

Unlike the political structures and forms of government in other European countries at that time, in Poland-Lithuania the monarchical system had evolved as a form of constitutional monarchy, which entailed extensive noble participation in the government. It is therefore unsurprising that the papal ambassadors should so readily describe the exceptional political system of Poland-Lithuania. ${ }^{58}$ One of the most thorough and thoughtful portrayals is that of Germanico Malaspina, whose report is characterised by a particularly sophisticated interest in political culture:

Poland is neither a real monarchy nor a true republic, but it contains elements of both forms of government. Not only does the King decide matters pertaining to defence, public order and security in peace and in war, but he does so together with the Senate and the nobility [...] That is why one could call it a republic. On the other hand, only the King can convene the Diet, and no resolution can be adopted without his permission, so that the shape of Polish government is more similar to the monarchical one. ${ }^{59}$

57 Ruggieri, p. 152: 'Benché vivano sotto un medesimo prencipe et facciano tutti insieme un corpo unito et quasi indistinto, non parlano però la medesima lingua, ma si odono in quel Regno tre linguaggi tra loro al tutto diversi. Uno de quali si divide in due differenti di scrittura, ma di pronuncia tanto simili che, sebbene variano li dialetti, conservano però la sostanza della medesima lingua. Et questi sono il linguaggio Polacco et il Russo; quello si scrive con caratteri Latini et questo con Greci. [...] Oltre alla quale lingua se ne odono nelli detti paesi due altre, al tutto diverse. Et queste sono la Lituana et la Tedesca.'

58 Dal Portico, pp. 30-38. See: Chynczewska-Hennel, Rzeczpospolita XVII Wieku, p. 122.

59 Malaspina, p. 75: 'Polska ani nie jest zupełnie monarchią, ani rzecząpospolitą, ale ma po części jeden, po części drugi kształt rządu, bo z jednej strony nie sam tylko król stanowi i wykonywa prace tyczące się obrony, porządku i bezpieczeństwa publicznego w pokoju i wojnie, lecz wspólnie z senatem i szlachtą, [...] i dlatego możnaby ją 
Malaspina's explanation was almost identical to that presented in the later report of Galeazzo Marescotti. ${ }^{60}$ Giulio Ruggieri noted that although the power of the King was limited, it was not as weak as it could seem:

That [royal] authority is in fact much greater than it appears. Being elected, he [the King] has the nobility's loyalty, affection and inclination towards his projects, as it is his prerogative to assign all vacant offices and ecclesiastical benefices and distribute them during the Diet's deliberations, as the rewards for those who show themselves to be devoted to him. ${ }^{61}$

Berardo Bongiovanni and Vincenzo Dal Portico also emphasised the decisiveness of the royal prerogative; the latter, however, judged the King's authority in a more pessimistic way:

His Majesty has little jurisdiction over the landed gentry, and over the ecclesiastics - none [...] The King cannot make wars and treaties, introduce taxes, or elect a successor, without the consent of the Senate. He cannot do it even with the consent of the Senate, if he lacks the permission of the nobility. ${ }^{62}$

The free royal election was another feature of Poland-Lithuania's unique political system which fascinated the papal nuncios. ${ }^{63}$ The

nazwać rzecząpospolitą; lecz że z drugiej strony nie kto inny tylko król sejm zwołać jest mocen, i że za nim żadna uchwała zapaść nie może bez jego zezwolenia, zatem idzie że kształt rządu polskiego zbliża się do monarchicznego.' NB: All fragments of relazioni finali quoted in Polish have been translated in the nineteenth century from Italian (or sometimes, but very rarely, from Latin); hence that is not their original linguistic version.

60 Marescotti I, p. 368.

61 Romano Ruggieri, Religione e Politica in Polonia tra Riforma e Controriforma (Pisa: Giardini, 1988), p. 39: 'Quella autorità riesce infatti molto maggiore che non è in apparenza, pressoché ellegendosi egli a gusto suo tutti li cavalieri viene in processo di tempo ad aver tutto il Consiglio obbligato, amorevole ed inclinato alle voglie e alli disegni suoi e appresso costuma il Re di tenere in mano tutti gli uffizi e le Chiese che successivamente vacano, per farne distribuzione nelle diete, come in premio di quelli che si sono dimostrati amorevoli suoi.'

62 Bongiovanni, p. 96; Dal Portico, p. 34: 'Sua Maestà contro i nobili laici ha poca giurisdittione, contro gl'ecclesiastici nessuna, non potendo sopra d'un nobile dove si tratta del pericolo della vita, della fama et de beni giudicare se non nella dicta col senato, né senza essa far guerra né lega, imporre nuove gabelle di denari et elegere il successore, non può né manco fare con il senato senza il consenso della nobiltà.'

63 Dal Portico, pp. 32-33. 
privilege of choosing the new sovereign belonged to all the nobles of the Kingdom. Alberto Bolognetti tried to explain in his report the roots of this ancient tradition, referring to the warrior origins of the royal title in Poland-Lithuania:

The Kingdom is not hereditary, even if they tend to elect the heir of the current King. This lack of heredity is believed to have been instituted by the ancient Sauromatians. They established a king merely for the necessities of war, choosing as their leader the bravest among them. ${ }^{64}$

The papal relazioni finali also contained some highly interesting descriptions of Polish-Lithuanian society. These accounts demonstrate the papal diplomats' attention to the lower classes' condition, even if there were no direct contacts between the nuncios and the peasantry. Vincenzo Dal Portico aptly and concisely described the social division in the Commonwealth: 'The Poles are people of three kinds: nobles, burghers and peasants. ${ }^{35}$ The nuncios repeatedly stressed the disastrously impoverished condition of the peasantry, and the absolute dominion of the nobility. ${ }^{66}$ Dal Portico's description of the social conditions of the peasants is striking:

The peasants, who are like slaves, cultivate the land, and are subjects of nobles, that possess their jus vitae without any right of appeal. [...] They live meanly, in such a way that in the depth of the winter, you can see a barefoot woman in her shirt walking through the snow. In their houses, they have no room other than a nook without a vent, always full of dense smoke; and they are often beaten by the lords for minor causes and even sometimes hanged. Even

${ }^{64}$ Alberto Bolognetti, Bolognetti Commentarii Rerum Polonicarum, [n.d.] in Monumenta Poloniae Vaticana: Alberti Bolognetti Nuntii Apostolici in Polonia Epistolae et Acta 1581-1585, ed. by Edward Kuntze and Czesław Nanke, 9 vols (Kraków: Cracoviae Sumptibus Academiae Litterarum Cracoviensis, 1913-1994), V/I (1923-1933), p. 683 (hereafter cited as: Bolognetti): 'Il Regno non è heriditario, se ben si eleggiono il più delle volte i figliuoli del Re; et in questo non essere hereditario si tiene l'istituto dei Sauromati antiqui, i quali non creavano Re per ordinario, ma occorrendo i bisogni di guerra, creavano capo il più valoroso di loro.'

65 Dal Portico, p. 19: 'Li Pollachi sono di tre sorte huomini: Nobili, cittadini e villani.'

${ }^{66}$ Lippomano, p. 300. See: Tygielski, 'Opinie Nuncjuszy', pp. 351-62 (p. 355); Tygielski, 'Geograficamente Distanti', pp. 226-35 (p. 230). 
when they have been killed without any cause, the noble assassin gets released with ten scudi. ${ }^{67}$

In the second half of the seventeenth century, Marescotti confirmed that this dreadful situation persisted:

The condition of Polish peasants that are held in the heavy yoke of bondage by the nobility is very unfortunate. This is because the landlords can not only torture the peasants, take from them whatever they want, but they can even take their lives. ${ }^{68}$

From the relazioni finali one can also discern some elements of the 'national character' of Poles. Luigi Lippomano emphasised the negative characteristics of the Polish temperament, writing that 'there is no justice, they thieve and kill, women get violated, people murder without any punishment, because the nobility has its privileges and cannot be judged but in the public Diet, in the King's presence.' 69 'They are the greatest admirers of themselves, so they feel great pleasure in being admired' Giulio Ruggieri rather caustically opined in another report. ${ }^{70} \mathrm{Dal}$ Portico admitted as well that Poles were fond of self-praise and valued their own possessions. ${ }^{71}$ Ruggieri added: 'They are very courageous and forceful in war, being [physically] bulky, well-built, and large of body. [...] They also have good intellectual capacities, but they are not

67 Dal Portico, p. 24: 'Li villani che sono come schiavi, lavorano la terra et sono sudditi di nobili, i quali hanno ius vitae senza appellatione; [...] ma per di più vivono meschinamente, in tal maniera che nel colmo dell'inverno si vedano le donne scalze et in camicia andare per la neve, che nelle case loro o non hanno altra stanza che una staffetta senza spiraglio, piene sempre di fumo densissimo; e sono spesse volte bastonate da patroni per cause legerissime et alle volte impicate; e benche siano amazzati senza causa, vien liberato l'homicida con 10 scudi.'

${ }^{68}$ Marescotti I, p. 366: 'Nieszczęśliwy jest bardzo stan chłopów polskich, których szlachta trzyma w ciężkim jarzmie niewoli; wolno jest bowiem panom nie tylko katować chłopów, zabrać co mają i co im się podoba, ale nawet odjąć im życie.'

${ }^{69}$ Lippomano, p. 300: 'Non vi è giustizia, si ruba, si assasina, si violano le donne, si amazza et non vi è chi castighi, perché la Nobiltà ha li suoi privilegii che non possa essere giudicata se non nei Comitii publici, presente il Re.'

70 Ruggieri, p. 151: 'Sono per il più grandi amatori di se stessi, onde nasce che sentono estremo piacere nell'esser adulati.'

71 Dal Portico, p. 18: 'Gran valutatori delle cose loro.' 
dedicated to intellectual pursuits. ${ }^{72}$ According to Marescotti, the Poles were 'proud people, but honest, sincere and frank. They rather tend to be deceived than to be able to fool anyone. They are so generous that they are almost sinful in their extravagance. ${ }^{73}$

Papal diplomats regularly commended the linguistic skills of the Poles. ${ }^{74}$ In Ruggieri's words, 'they have an astonishing facility to learn the languages and customs of foreign nations and to adapt all their clothes and manners to them. ${ }^{75} \mathrm{Dal}$ Portico confirmed this opinion in his later report: 'They adapt themselves to the foreign languages and costumes admirably, also to the Italian ones. They familiarise themselves with Italian culture and the language better than any other ultramontane nation. ${ }^{76}$ During the seventeenth century, Honorato Visconti and Galeazzo Marescotti again stressed the language abilities of the Polish-Lithuanian nobility. ${ }^{77}$

Furthermore, the papal diplomats also left information about the customs and traditions of the local people. Bolognetti's description of aristocratic marriage ceremonies is particularly intriguing:

The authors write that Sarmatians traditionally stayed three days at their banquet tables. It seemed unbelievable before I went there, but I then found that at weddings one remains at the table from dinner until midnight, with food arriving every single hour, while in the same place they dance. ${ }^{78}$

72 Ruggieri, p. 151: 'Sono però nella guerra molto animosi et robusti, per esser carnosi, ben complessi et grandi di corpo. [...] Hanno per il più buona capacità d'inteletto, ma non molto si essercitano nello studio.'

73 Marescotti I, p. 366: 'Ludzie dumni, ale rzetelni, szczerzy i uczciwi, częściej bywają oszukani niż potrafią kogo oszukać. Są tak hojni, że grzeszą prawie rozrzutnością.' See: Chynczewska-Hennel, Rzeczpospolita XVII Wieku, p. 197.

74 Chynczewska-Hennel, Rzeczpospolita XVII Wieku, pp. 22-23.

75 Ruggieri, p. 151: 'Hanno ancora un incredibil facilità ad apprendere le lingue e li costumi delle nationi straniere et transformarsi in quelle quanto a gl'habiti et a tutte le maniere d'esse.'

76 Dal Portico, p. 23: 'Si accomodano mirabilmente alle lingue et a costumi de forestieri et medesime a quelle dell'Italiani, apprendendo più di qualunque altra natione ultramontana le usanze et la lingua italiana.'

77 Visconti, p. 237; Marescotti I, p. 366.

78 Bolognetti, p. 685: 'Scrivono gl'authori che i Sarmati stavano tre giorni a tavola ne'loro banchetti, il che mi pareva incredibile prima ch'io v'andassi, ma trovai poi che 
The nuncios were attentive to everything which differed from the Italian customs to which they were accustomed. Berardo Bongiovanni noted, for example, the ubiquity of the handshake as the most common form of greeting. Food and drink attracted particular attention from the nuncios. They that the Polish nobility did not particularly care for wine. 'They do not produce wine, although they have grapes, especially in Lesser Poland. Even though those grapes are good to eat, they make bitter wine' wrote Dal Portico, perhaps in tones of lamentation. ${ }^{79} \mathrm{He}$ emphasised also the high prices of imported wines and noticed the nobility's predilection for different varieties of beer instead of wine. ${ }^{80}$ Berardo Bongiovanni provided some information on the culture of drinking in Poland-Lithuania: 'Drunk people are called cheerful, and it is no shame to be raised from the table omnibus videntibus and to be taken by the arm to be brought home. ${ }^{31}$ Ruggieri wrote that 'among them it is praiseworthy to get drunk, as it is an evident sign of benign nature. ${ }^{92}$ Alberto Bolognetti similarly stressed the Poles' inclination and enthusiasm for alcohol. He wrote that even the nobles 'get sick when drinking toasts for the others, and drinking is highly regarded here to such an extent that guests are not considered to have been treated

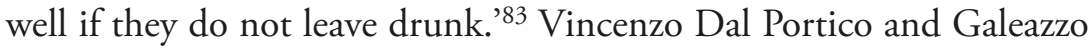
Marescotti likewise passed comment on the propensity of Poles to

nelle nozze si stava a tavola dei desinare sin'a mezzanotte, portandosi vivande nove ciascun'hora, oltre questo primo apparato, mentre intanto nel medesimo luogo si balla.'

79 Dal Portico, p. 8: 'Vini non si produce, se bene ha dell'uva in qualche parte, e massime nella Minor Pollonia, perché se bene è buona da mangiare, fa però il vino acerbo.'

${ }^{80}$ Ibid., pp. 27-28.

${ }^{81}$ Letter from Berardo Bongiovanni to Giovanni Morone, 4 September 1562, in Elementa ad Fontium Editiones: Documenta ex Archivo Cardinalis Ioannis Morone ad Poloniam Spectantia quae in Archivo Secreto et in Bibliotheca Vaticana Asservantur, I pars, ed. by Carolina Lanckorońska, 76 vols (Rome: Institutum Historicum Polonicum Romae, (1960-1996), LVIII (1984), p. 80: 'Per li imbriachi che qui si chiamano allegri, et non è vergogna esser portato a braccio a casa et levato da tavola omnibus videntibus.'

${ }^{82}$ Ruggieri, p. 151: 'Appresso di loro l'inebriarsi cosa cosa laudabile et quasi evidente segno di benigna natura.'

83 Bolognetti, p. 693: 'S'ammalano bevendo per salute d'altri e dedili all'hebrieta, talche non si reputa che gl'invitati siano stati trattati bene, se non si partono embriachi.' 
drink alcohol. ${ }^{84}$ Regarding eating customs, Dal Portico noted a vast consumption of meat among the nobility. He reported that one Polish nobleman would eat the same amount of meat as five Italians would do normally. On the other hand, he pointed out that, in contrast to Italy, in Poland-Lithuania people ate hardly any bread or vegetables. ${ }^{85}$ The papal diplomats wrote extensively about the moral condition and different abuses of the Polish clergy - these were subjects perhaps of more direct interest to their readers at the Curia. The ethical problems and abuses which the nuncios perceived were mainly the following: alcoholism, consorting with women, a low level of education, and lack of attention to the fasts dictated by the Church calendar. Honorato Visconti was particularly censorious of the bishops:

They usually enter the episcopal see with scarcely any of the knowledge necessary to hold this high dignity. They often do not know even the meaning of the word bishop. It seems that many of them are more proud to be senators than bishops. On their writing-tables, you can more often see an opened political treatise than you can a breviary or a pontifical. They are more concerned with temporal affairs than with their ecclesiastical obligations. ${ }^{86}$

Confessional issues occupied an important place in the final reports. ${ }^{87}$ One of the papacy's principal concerns in Poland-Lithuania was the spread of heresy, particularly during the sixteenth century. Giulio Ruggieri confirmed the complex confessional situation of the Kingdom, comparing Poland-Lithuania to the Tower of Babel:

The heretics do not belong to any one sect. They have renewed here the ancient Tower of Babel and so they preach together all the heresies that I know of or that have been heard of. Those persecuted in other places are welcomed here, this

${ }^{84}$ Dal Portico, p. 22; Marescotti I, p. 366.

85 Dal Portico, p. 28.

${ }^{86}$ Visconti, p. 235: 'Postępują zazwyczaj na godność biskupią z tak małym zapasem wiadomości potrzebnych do piastowania tego wysokiego dostojeństwa, że częstokroć nie znają znaczenia wyrazu biskup. Zdaje się że wielu z nich chlubi się więcej tytułem senatora niżeli biskupa, a na ich stoliku prędzej zobaczysz otwartą xsiążkę traktującą o polityce niżeli brewiarz lub pontyfikał, są bardziej zajęci sprawami świeckimi niżeli obowiązkami stanu duchownego.'

${ }^{87}$ Chynczewska-Hennel, Rzeczpospolita XVII Wieku, p. 129. 
Kingdom being their last safe refuge. [...] The Lutheran confession was the most famous and the most popular in Greater Poland and Prussia, even though it now is on the wane. The Calvinist doctrine, on the contrary, is widespread in Lesser Poland. In this way one form of heresy is fighting the other. ${ }^{88}$

At the same time, Mazovia was recognised as the most Catholic region of the Kingdom. ${ }^{89}$ Interestingly, Bongiovanni and Dal Portico mentioned in their reports some elements of pagan worship which still endured in various regions of the Commonwealth (particularly in Lithuania and Samogitia). ${ }^{90}$

Dal Portico emphasised the noble character of the Reformation in Poland-Lithuania, regretting the subordination of peasants to their superiors in religious matters. ${ }^{91}$ On the other hand, Alberto Bolognetti confirmed the fervent religiosity evident at all levels of society, as demonstrated by the widespread saintly and devotional cults: 'They carry out various extra ceremonies in the church, such as processions and orations. ${ }^{\prime 2}$ Eventually, in broad terms, the Counter-Reformation triumphed in Poland-Lithuania in the seventeenth century. Galeazzo Marescotti reported (rather immodestly) that:

[...] by the grace of God, the Catholic religion flourishes in Poland and its provinces, and one can expect its preservation and growth thanks to the vigilance of the King, to the zeal of the bishops and to the apostolic nuncio's help. ${ }^{93}$

88 Ruggieri, p. 168: 'Li eretici non sono d'una sola setta, hanno ivi rinnovata l'antica torre di Babele et così si predicano insieme tutte la eresie che oggi dì ho ritrovato o rinnovate s'odono; et quelli che sono cacciati d'ogni banda si ricoverano in quello regno come in suo ultimo et sicuro rifugio. [...] La luterana è stata sin qui più celebre et più commune nella Polonia Maggiore et nella Prussia, benché hora comincia a declinare; la calvinista, all'incontro, ha maggior piede nella Polonia Minore et così altre vanno scacciando l'una l'altra.'

89 Dal Portico, p. 96; Ruggieri, p. 168.

90 Dal Portico, p. 99; Bongiovanni, p. 98.

91 Dal Portico, p. 96.

92 Bolognetti, p. 690: 'Usano nella chiesa varie cerimonie di piu, come di processioni et orationi.'

93 Marescotti, p. 405: 'Religia katolicka kwitnie z łaski Boga w Polsce tudzież w zjednoczonych z nią prowincyach, i spodziewać się można jej zachowania i pomnożenia przy czujności króla, gorliwości biskupów i pomocy nuncyusza apostolskiego.' 
Moreover, papal diplomats principally directed their attention towards the main cities of Poland-Lithuania. ${ }^{94}$ In fact, the nuncios left considerable volumes of information regarding urban settlements and their characteristics. They tended to notice the inferior levels of urbanization in Rzeczpospolita..$^{95}$ The papal envoys often complained about the bad road system in Poland-Lithuania, which in certain months of the year made it nearly impossible to travel., This was unfortunate for the nuncios, who were frequently on the move when following the itinerant royal court.

The relazioni finali referred also to the resources of the state, confirming the importance of agriculture as the basis of the Polish-Lithuanian economy. ${ }^{96}$ Among exported goods, the nuncios listed silver, grains, rye, corn, legumes, linens, wax, ash, fruit such as pears, apples and similar, wood, horses, bulls and other domestic animals. ${ }^{97}$ Among the imports were wines, silk, wool, tapestries, carpets, olives, oils, groceries and furs. ${ }^{98}$ Considering the importance of the grain market, the nuncios paid special attention to the systems of navigation on the Commonwealth's rivers, which conducted transports of grain to and from the merchant cities. ${ }^{99}$ Another important element of Polish trade was amber. Vincenzo Dal Portico described the procedure of seeking Baltic amber, which was subsequently refined and sold in harbour cities such as Danzig and Königsberg. ${ }^{100}$ Furthermore, the nuncios underscored the importance of the salt mines for Commonwealth's exchequer. 'The mine at Wieliczka, near to Cracow [...], is one of the largest salt mines in the world' reported Vincenzo Dal Portico. ${ }^{101}$ In addition, Dal Portico noticed that trade in Poland-Lithuania was executed solely by foreigners, namely Jews, Armenians, Germans, and Italians. Nobles were involved exclusively in the sale of grain from their own farms. ${ }^{102}$

${ }_{94}$ Litwin, pp. 110-11.

95 Lippomano, p. 298.

96 Tygielski, 'Opinie Nuncjuszy', 351-62 (pp. 354-55).

97 Ruggieri, p. 149; Dal Portico, p. 29.

98 Dal Portico, p. 29; Ruggieri, p. 192.

99 Lippomano, p. 299; Dal Portico, p. 12.

${ }^{100}$ Dal Portico, p. 9.

101 Ibid., pp. 9-12: 'Quella che è a Wieliczka, castello presso a Cracovia [...], è una delle maggiori miniere di sale che si trovi al mondo.' See: Ruggieri, p. 150; Bongiovanni, p. 97.

102 Dal Portico, p. 28. 


\section{THE IMAGINE EMERGED}

The aim of this article was to prove the importance of relazioni finali as a form of cultural message. It was my intention to present this genre of document as a source rich in various information, as a kind of future instruction for future papal nuncios, but above all, as a cultural contribution, created to address the Curia's lack of knowledge of the Polish-Lithuanian Commonwealth. Moreover, I would like to emphasise that the analysis of diplomatic sources does not necessarily mean producing a purely political history, focused on wars, political treaties, and prominent courtly individuals. It also offers an opportunity to consider various aspects of social, cultural and daily life.

Through a detailed reading of the final reports, it was possible to reconstruct, at least partially, the overarching image of the early modern Polish-Lithuanian Commonwealth, as the papal diplomats viewed it. It was important to devote attention to the question as to which issues aroused the particular interest of successive Popes, and which specific questions were deposited in the reports. Were the papal nuncios able to understand fully the political, social and economic conditions of the state - conditions that were so often different from those with which they were familiar? ${ }^{203}$ What image of Poland-Lithuania emerges from the documents produced by the ambassadors of the Holy See? It is possible to sustain the argument that Rzeczpospolita constituted for the papal diplomats a geographically distant world, characterised by strong cultural diversity. On the other hand, the Polish-Lithuanian Commonwealth could not have been completely alien to the nuncios. Many nobles from the Commonwealth received their education in what one might call Western universities; spoke, wrote and understood not only Latin, but also Italian and German; and were prominent in the political and cultural tableau of early modern Europe more generally.

The process of gathering information focused more on the longer-term policy objectives and less so on specific matters. The papal diplomats could draw upon their own observations, but could also collaborate with court dignitaries, other foreign ambassadors, and the murky world of espionage. The nuncios also relied on the information which

103 Tygielski, 'Geograficamente Distanti', pp. 226-35 (p. 226). 
their own chancellery collected regularly. They used local reports and chronicles, especially in order to provide a historical background of the country they were describing. In the case of the Polish-Lithuanian Commonwealth, the papal diplomats extensively mined the chronicles of Jan Długosz. ${ }^{104}$ In any case, the quality of a relazione finale would depend also on the personal literary talent of a certain diplomat, as well as on his experience and knowledge of the subjects he wrote about. ${ }^{105}$

The practice of providing final reports certainly made it easier for the Holy See to conduct a longer-term policy in Central and Eastern Europe in the early modern era. It also facilitated increased knowledge of the social and political features of the enormous 'noble' republic. However, were the relazioni finali truly essential for the Roman Curia, to allow them to acquire a practical awareness of Poland-Lithuania? It does not seem so, as plenty of far more detailed information on both political and social issues emerge clearly from the nuncios' regular diplomatic correspondence. ${ }^{106}$ The final reports, however, constitute an extraordinary documentary template, in which diplomats were trying to collate and analyse the vast swathes of information they collected during the mission. The relazioni finali therefore remain unusual and fascinating testimonies to the challenges and the realities of diplomatic service in unknown - even 'barbarous' - reaches of the continent. ${ }^{107}$

The picture of Poland-Lithuania that emerges from these documents is extremely vivid. As Wojciech Tygielski stated, 'the nuncios became [by means of their verbal and written relations] a group of authors creating a literary portrait of early modern Poland-Lithuania.' ${ }^{108}$ Moreover, the

104 Marescotti I, p. 365.

105 Queller, pp. 174-96 (pp. 179-180); Tygielski, 'Geograficamente Distanti', pp. 226-35 (p. 226). We have an example of Cosimo de Torres' relazione, which was poorly original and did not bring a lot of new knowledge or opinions about the Polish-Lithuanian context. See: Litwin, p. 167.

106 Wojtyska, Papiestwo - Polska, pp. 204-07; Chynczewska-Hennel, 'Le Relazioni dei Nunzi Apostolici sulla Polonia nell'Età Moderna: Introduzione alla Problematica', in Nel Mondo degli Slavi: Incontri e Dialoghi tra Culture. Studi in Onore di Giovanna Borgi Bercoff, ed. by Maria di Salvo, Giovanna Moracci and Giovanna Siedina (Florence: Firenze University Press, 2008), pp. 85-94; Tallon, pp. 195-96.

107 See: Dursteler, 232-48.

108 Tygielski, Z Rzymu do Rzeczypospolitej, p. 64: 'Nuncjusze stali się w ten sposób zbiorowym autorem portretu nowożytnej Rzeczypospolitej.' 
reports analysed above are not limited to descriptions of the events that occurred in a purely chronological way. On the contrary, they are emotionally charged, manifesting the nuncios' various attitudes and sentiments towards the new reality in which the papal diplomats had found themselves. Therefore, the relazioni finali contributed strongly to the creation of a cultural idea of the Polish-Lithuanian Commonwealth, both in Rome and throughout the whole of Europe.

\section{BIBLIOGRAPHY}

Archival Sources

Rome, Archivio Segreto Vaticano

Segreteria di Stato, Polonia

$5 b$

Krakow, Biblioteka Naukowa PAU/PAN w Krakowie

Teka Rzymska

127

\section{Printed Primary Sources}

Acta Nuntiaturae Polonae: De fontibus eorumque investigatione et editionibus. Instructio ad editionem. Nuntiorum series chronologica, ed. by Henryk Damian Wojtyska (Rome: Institutum Historicum Polonicum Romae, 1990-2016), I (1990)

Acta Nuntiaturae Polonae: Aloisius Lippomano (1555-1557), ed. by Henryk Damian Wojtyska (Rome: Institutum Historicum Polonicum Romae, 1990-2016), III (1992)

Acta Nuntiaturae Polonae: Iulius Ruggieri (1565-1568), ed. by Stanisław Bogaczewicz and Tadeusz Glemma (Rome: Institutum Historicum Polonicum Romae, 1990-2016), VI (1992)

Acta Nuntiaturae Polonae: Honoratius Visconti (1630-1636), ed. by Wojciech Biliński (Rome: Institutum Historicum Polonicum Romae, 1990-2016), XXIV/1 (1992) Cudzoziemcy w Polsce. Relacje i Opinie, ed. by Jan Gintel, 2 vols (Kraków: Wydawnictwo Literackie, 1971)

Dykmans, Marc, Le Céremonial Papal de la Fin du Moyen Age à la Renaissance. II: De Rome en Avignon ou le Céremonial de Jacques Stefaneschi (Brussels: Institut Historique Belge de Rome, 1981)

Monumenta Poloniae Vaticana: Alberti Bolognetti Nuntii Apostolici in Polonia Epistolae et Acta 1581-1585, ed. by Edward Kuntze and Czesław Nanke, 9 vols (Kraków: Cracoviae Sumptibus Academiae Litterarum Cracoviensis, 1913-1994), V/I (1923-1933) 
Elementa ad Fontium Editiones: Documenta ex Archivo Cardinalis Ioannis Morone ad Poloniam Spectantia quae in Archivo Secreto et in Bibliotheca Vaticana Asservantur, I pars, ed. by Carolina Lanckorońska, 76 vols (Rome: Institutum Historicum Polonicum Romae, 1960-1996), LVIII (1984)

Relacye Nuncyuszów Apostolskich i Innych Osób o Polsce od Roku 1548 do 1690, ed. by Erazm Rykaczewski, 2 vols (Berlin: Biblioteka Polska w Paryżu, 1864)

\section{Secondary Works}

Anderson, Matthew Smith, The Rise of Modern Diplomacy 1450-1919 (London: Longman, 1993)

Andretta, Stefano, L'Arte della Prudenza: Teorie e Prassi della Diplomazia nell'Italia del XVI e XVII Secolo (Rome: Biblink, 2006)

Bély, Lucien, 'Histoire de la Diplomatie et des Relations Internationales des Temps Modernes: Un État de la Recherche en France', in Sulla Diplomazia in Età Moderna: Politica, Economia, Religione, ed. by Renzo Sabbatini and Paola Volpini (Milan: FrancoAngeli, 2011), pp. 19-34

Bodniak, Stanisław, 'Polska w Relacji Włoskiej z Roku 1604', Pamiętnik Biblioteki Kórnickiej, 2 (1930), 26-49

Brezzi, Paolo, La Diplomazia Pontificia (Milan: Istituto per gli Studi di Politica Internazionale, 1942)

Chynczewska-Hennel, Teresa, Rzeczpospolita XVII Wieku w Oczach Cudzoziemców (Wrocław: Zakład Narodowy im. Ossolińskich, 1993)

— zione alla Problematica', in Nel Mondo degli Slavi: Incontri e Dialoghi tra Culture. Studi in Onore di Giovanna Borgi Bercoff, ed. by Maria di Salvo, Giovanna Moracci and Giovanna Siedina (Florence: Firenze University Press, 2008), pp. 85-94

Dursteler, Eric, 'Describing or Distorting the "Turk"? The Relazioni of the Venetian Ambassadors in Constantinople as Historical Sources', Acta Histriae, 19 (2011), $232-48$

Frigo, Daniela, 'Politica Estera e Diplomazia: Figure, Problemi e Apparati', in Storia degli Antichi Stati Italiani, ed. by Gaetano Greco and Mario Rosa (Rome: Laterza, 1996), pp. 117-61

Litwin, Henryk, Chwata Pótnocy: Rzeczpospolita w Europejskiej Polityce Stolicy Apostolskiej w Pierwszej Potowie XVII Wieku (1599-1648) (Lublin: KUL, 2013)

Queller, Donald, 'The Development of Ambassadorial Relazioni', in Renaissance Venice, ed. by John Rigby Hale (London: Faber and Faber, 1973), pp. 174-96

Riccardi, Luca, 'An Outline of Vatican Diplomacy in the Early Modern Age', in Politics and Diplomacy in Early Modern Italy: The Structure of Diplomatic Practice, 1450-1800, ed. by Daniela Frigo (Cambridge: Cambridge University Press, 2000), pp. $95-108$

Ruggieri, Romano, Religione e Politica in Polonia tra Riforma e Controriforma (Pisa: Giardini, 1988) 
Tallon, Alain, L'Europa del Cinquecento: Stati e Relazioni Internazionali (Rome: Carocci, 2013)

Tygielski, Wojciech, Z Rzymu do Rzeczypospolitej: Studia z Dziejów Nuncjatury Apostolskiej $w$ Polsce, XVI-XVII $w$. (Warsaw: Wydawnictwa Fundacji 'Historia pro Futuro', 1992)

—_, 'Opinie Nuncjuszy Apostolskich na Temat Polski XVI-XVII w.', Przeglad Historyczny, 85 (1994), 351-62

—_, 'Geograficamente Distanti ma Spiritualmente Vicini: La Realtà Politica e Sociale Polacca del XVI e del XVII Secolo agli Occhi dei Nunzi Apostolici', in Kurie und Politik: Stand und Perspektiven der Nuntiaturberichtsforschung, ed. by Alexander Koller (Tübingen: Niemeyer, 1998), pp. 226-35

—_ , 'Źródła Informacji Papieskich Dyplomatów', in Nuncjatura Apostolska $w$ Rzeczypospolitej, ed. by Teresa Chynczewska-Hennel and Katarzyna Wiszowata-Walczak (Białystok: IHiNP UWB, 2012), pp. 27-44

Visceglia, Maria A., Roma Papale e Spagna: Diplomatici, Nobili e Religiosi tra le Due Corti (Rome: Viella, 2010)

Wojtyska, Henryk Damian, Papiestwo - Polska 1548-1563 (Lublin: Towarzystwo Naukowe Katolickiego Uniwersytetu Lubelskiego, 1977)

—- Acta Nuntiaturae Polonae: De Fontibus Eorumque Investigatione et Editionibus Instructio ad Editionem Nuntiorum Series Chronologica (Rome: Institutum Historicum Polonicum Romae, 1990-2016), I (1990)

Woś, Jan W., Fonti per la Storia della Nunziatura Polacca di Annibale di Capua (1586-1591) (Trento: Università di Trento, Dipartimento di Scienze Filologiche e Storiche, 1992)

Dorota Gregorowicz - received her PhD from Università degli Studi del Piemonte Orientale 'Amedeo Avogadro'; e-mail: gregra1@wp.pl 